\title{
Characterization of Borrelia lusitaniae sp. nov. by 16S Ribosomal DNA Sequence Analysis
}

\author{
ANNE LE FLECHE, ${ }^{1}$ DANIELE POSTIC, ${ }^{1 *}$ KARINE GIRARDET, ${ }^{2}$ OLIVIER PETER, ${ }^{2}$ \\ AND GUY BARANTON ${ }^{1}$ \\ Unité de Bactériologie Moléculaire et Médicale, Institut Pasteur, 75724 Paris Cedex 15, France, ${ }^{1}$ and Clinical \\ Microbiology, Institut Central des Hôpitaux Valaisans, 1950 Sion, Switzerland ${ }^{2}$
}

\begin{abstract}
We determined the complete sequence of the rrs gene from five strains of genomic species PotiB2. Both distance and parsimony methods were used to infer the evolutionary relationships of the rrs gene sequence of this genomic species in comparison with the rrs gene sequence of Borrelia valaisiana and the rrs gene sequences of Borrelia burgdorferi sensu lato species obtained from sequence databases. The phylogenetic analysis revealed that the genomic species PotiB2 strains clustered in a separate lineage, which was consistent with data from previous DNA-DNA hybridization experiments (D. Postic, M. V. Assous, P. A. D. Grimont, and G. Baranton, Int. J. Syst. Bacteriol. 44:743-752, 1994). A PCR-restriction fragment length polymorphism analysis was used to identify genomic species PotiB2 and to differentiate it from $B$. burgdorferi sensu lato species. Moreover, signature nucleotide positions were identified for each $B$. burgdorferi sensu lato species. In accordance with DNA relatedness values, our findings suggest that genomic species PotiB2 can be more clearly defined and identified, and we propose that it should be referred to as a new species, Borrelia lusitaniae. The type strain is PotiB2.
\end{abstract}

Borrelia burgdorferi sensu lato, the causative agent of Lyme borreliosis, has been previously divided into five well-defined species, B. burgdorferi sensu stricto, Borrelia garinii, Borrelia afzelii $(1,4)$, Borrelia japonica $(12,22)$, and Borrelia andersonii (17). The pathogenicity for humans of the first three species has been well-established, whereas the last two species seem not to be pathogenic for humans. These different species are not equally distributed all over the world, since the three main species, B. garinii, B. afzelii, and B. burgdorferi sensu stricto, occur in Europe, whereas B. burgdorferi sensu stricto is absent from Asia and is the main species encountered in the United States. In the United States, the more recently described species $B$. andersonii is also present as genomic species DN127, and each of the species is restricted to a limited geographical area. Additionally, in Japan, two species, Borrelia tanukii and Borrelia turdae, were described recently $(6,7)$. In Europe, two genomic species that are genetically and phenotypically divergent, genomic species VS116 and PotiB2, have been reported $(20,21)$. The name Borrelia valaisiana is proposed in the accompanying paper for genomic species VS116 (29). Genomic species PotiB2 has been identified previously by DNA-DNA hybridization and has been characterized on the basis of the sequence of its $r f-r r l$ ribosomal spacer (21). A specific MseI restriction pattern allowed workers to clearly identify this new genomic species, as well as all other delineated species or genomic species.

The aim of this study was to further characterize genomic species PotiB2. First, characterization was completed at a genomic level by sequencing the $r r s$ gene, which yielded an alternative means for specific identification. Second, the strains were studied at a phenotypic level with an analysis of protein patterns. On the basis of the present work and previous results, we propose that genomic species PotiB2 should be named Borrelia lusitaniae sp. nov.

* Corresponding author. Mailing address: Unité de Bactériologie Moléculaire et Médicale, Institut Pasteur, 28 rue du Docteur Roux, 75724 Paris Cedex 15, France. Phone: 331456883 37. Fax: 3314061 30 01. E-mail: dpostic@pasteur.fr.

\section{MATERIALS AND METHODS}

Bacterial strains. The designations and origins of the Borrelia strains used in this study are given in Table 1. Five strains, PotiB1, PotiB2 ${ }^{\mathrm{T}}$, PotiB3, Ir345, and BR41, belong to genomic species PotiB2. For the phenotypic analysis, the following representative strains were included: $B$. burgdorferi sensu stricto strain $\mathrm{B} 31^{\mathrm{T}}$, B. garinii $20047^{\mathrm{T}}$, and $B$. afzelii $\mathrm{VS} 461^{\mathrm{T}}$. The isolates were grown in BSK II medium at $30^{\circ} \mathrm{C}$ (2) for 4 to 10 days until the density reached about $10^{8}$ bacteria/ml.

DNA preparation. A $1.5-\mathrm{ml}$ portion of culture was required for DNA extraction. Cells were harvested by centrifugation $(12,000 \times g, 15 \mathrm{~min})$ and washed in phosphate-buffered saline ( $\mathrm{pH}$ 7.2). DNA was extracted with a Dynabeads DNA direct kit (Dynal), a method based on DNA separation by biomagnetic beads. Finally, DNA was eluted in $30 \mu$ lof TE buffer (10 mM Tris- $\mathrm{HCl}$ [pH 8.0], $1 \mathrm{mM}$ EDTA). This suspension was stored at $-20^{\circ} \mathrm{C}$ until it was required for PCR experiments.

Solid-phase DNA sequencing of PCR products. We used a solid-phase approach to sequence DNA from PCR products. During the PCR, biotin was introduced into one of the strands by using one of the primers biotinylated at the $5^{\prime}$ end. We used a primer set consisting of primers $\mathrm{fD} 3$ and UniB (Table 2) to amplify approximately $1,500 \mathrm{bp}$ of the $r s$ gene. Each PCR mixture $(50 \mu \mathrm{l})$ contained $5 \mu \mathrm{l}$ of DNA, $10 \mathrm{mM}$ Tris- $\mathrm{HCl}, 1.5 \mathrm{mM} \mathrm{MgCl}, 50 \mathrm{mM} \mathrm{KCl}, 0.01 \%$ gelatin, each of the four deoxynucleotide triphosphates at a concentration of 200 $\mu \mathrm{M}, 1.25 \mathrm{U}$ of Taq polymerase (Amersham), $2.5 \mu \mathrm{M}$ biotinylated primer, and the second primer at a concentration of $5 \mu \mathrm{M}$. The reaction mixtures were overlaid with mineral oil $(50 \mu \mathrm{l})$. Each amplification reaction was carried out for 35 cycles consisting of denaturation at $93^{\circ} \mathrm{C}$ for $1 \mathrm{~min}$, annealing at $50^{\circ} \mathrm{C}$ for $1 \mathrm{~min}$, and extension at $72^{\circ} \mathrm{C}$ for $1 \mathrm{~min}$, and this was followed by extension at $72^{\circ} \mathrm{C}$ for $9 \mathrm{~min}$ Negative controls were included in all experiments. The PCR products were detected by electrophoresis in a $0.8 \%$ agarose gel in $1 \times$ TBE and then stained with ethidium bromide.

The PCR product was then immobilized through the interaction between biotin and streptavidin by using a Dynabeads M-280 streptavidin kit (Dynal) according to the manufacturer's instructions. The DNA strands were separated in a $0.1 \mathrm{M} \mathrm{NaOH}$ solution, and the biotinylated strand was immobilized by using Dynal MPC (Dynal) and finally eluted in $12 \mu \mathrm{l}$ of water.

The $r$ rs gene was sequenced by using a Cy5-AutoRead sequencing kit (Pharmacia) according to the manufacturer's instructions. Briefly, the sequencing primer $(10 \mathrm{pmol})$ was annealed to the biotinylated single-stranded template in the appropriate buffer at $65^{\circ} \mathrm{C}$ for $10 \mathrm{~min}$ and then at $37^{\circ} \mathrm{C}$ for $10 \mathrm{~min}$ and finally cooled at room temperature for $10 \mathrm{~min}$. In the second step Cy5-dATP labelling mixture (Pharmacia) was incorporated, and the labelling reaction was started by adding T7 DNA polymerase $(3 \mathrm{U})$. Termination reactions were performed by adding the labelling reaction mixture to each of the four dideoxynucleotide sequencing mixtures. Six percent polyacrylamide gels in an ALF express automatic sequencer (Pharmacia) were used for sequencing reactions. Both strands of the $r$ rs gene of all strains were sequenced at least twice.

Sequence alignments and phylogenetic analysis. Sequences were aligned both manually with VSM software (version 2.0) written by B. Lafay and R. Christen 
TABLE 1. Strains used in this study

\begin{tabular}{|c|c|c|c|c|}
\hline Strain & Geographic origin & Source ${ }^{a}$ & $\begin{array}{l}\text { GenBank accession no. } \\
\text { for } r r s \text { gene (reference) }\end{array}$ & $\begin{array}{l}\text { Sizes (bp) of } B f a I \text { fragments } \\
\text { of amplified } r r s \text { gene }\end{array}$ \\
\hline $\begin{array}{l}\text { B. lusitaniae strains } \\
\text { PotiB1 } \\
\text { PotiB2' } \\
\text { PotiB3 } \\
\text { Ir345 } \\
\text { BR41 }\end{array}$ & $\begin{array}{l}\text { Portugal } \\
\text { Portugal } \\
\text { Portugal } \\
\text { Belorussia } \\
\text { Czech Republic }\end{array}$ & $\begin{array}{l}\text { Ixodes ricinus } \\
\text { Ixodes ricinus } \\
\text { Ixodes ricinus } \\
\text { Ixodes ricinus } \\
\text { Ixodes ricinus }\end{array}$ & $\begin{array}{l}\text { X98226 (this study) } \\
\text { X98228 (this study) } \\
\text { X98229 (this study) } \\
\text { X98230 (this study) } \\
\text { X98231 (this study) }\end{array}$ & $689,404,159,100,78,58$ \\
\hline $\begin{array}{l}\text { B. valaisiana strains } \\
\text { VS116 } \\
\text { UK } \\
\text { Am501 }\end{array}$ & $\begin{array}{l}\text { Switzerland } \\
\text { England } \\
\text { Japan }\end{array}$ & $\begin{array}{l}\text { Ixodes ricinus } \\
\text { Ixodes ricinus } \\
\text { Ixodes } \\
\text { columnae }\end{array}$ & $\begin{array}{l}\text { X98232 (29) } \\
\text { X98233 (29) } \\
\text { D67021 (6) }\end{array}$ & $689,504,159,78,58$ \\
\hline $\begin{array}{l}\text { B. burgdorferi strains } \\
\text { DK7 } \\
\text { Lipitz }\end{array}$ & $\begin{array}{l}\text { Denmark } \\
\text { United States }\end{array}$ & $\begin{array}{l}\text { Skin } A C A \\
\text { Skin }\end{array}$ & $\begin{array}{l}\text { X85195 (28) } \\
\text { X85203 (28) }\end{array}$ & $689,404,236,159$ \\
\hline $\begin{array}{l}\text { B. garinii strains } \\
\text { PBi } \\
\text { DK27 }\end{array}$ & $\begin{array}{l}\text { Germany } \\
\text { Denmark }\end{array}$ & $\begin{array}{l}\text { CSF } \\
\text { Skin EM }\end{array}$ & $\begin{array}{l}\text { X85199 (28) } \\
\text { X85193 (28) }\end{array}$ & $689,404,159,158,78$ \\
\hline $\begin{array}{l}\text { B. afzelii strains } \\
\text { DK1 } \\
\text { DK21 }\end{array}$ & $\begin{array}{l}\text { Denmark } \\
\text { Denmark }\end{array}$ & $\begin{array}{l}\text { Skin EM } \\
\text { Skin EM }\end{array}$ & $\begin{array}{l}\text { X85190 (28) } \\
\text { X85191 (28) }\end{array}$ & $689,504,159,136$ \\
\hline B. japonica $\mathrm{HO} 14^{\mathrm{T}}$ & Japan & Ixodes ovatus & L40597 (8) & $689,504,159,136$ \\
\hline B. andersonii $21308^{\mathrm{T}}$ & United States & Ixodes dentatus & L46701 (17) & $689,404,159,136,100$ \\
\hline $\begin{array}{l}\text { Genomic species DN127 } \\
\text { strain DN127 }\end{array}$ & United States & Ixodes pacificus & L40596 (8) & $689,404,236,159$ \\
\hline
\end{tabular}

${ }^{a} \mathrm{ACA}$, acrodermatitis chronica atrophicans; EM, erythema migrans; CSF, cerebrospinal fluid.

as described previously (25) and by using multisequence alignment program Clustal V software (10).

Phylogenetic relationships were analyzed by using three methods, and the results were compared. A most-parsimonious tree was constructed by using the PAUP (Phylogeny Analysis Using Parsimony) program (27). Evolutionary distances were computed with the Jukes-Cantor option (26) by using both the PHYLIP program package written by Felsenstein (5) and MEGA software (14). Phylogenetic trees were constructed by using the Kitsch + genetic distance algorithm from distance matrix data and by using the neighbor-joining method (26) in MEGA. The rrs sequences of $B$. lusitaniae sp. nov. were compared to the sequences of other $B$. burgdorferi sensu lato species.

Restriction fragment length polymorphism analysis of PCR products. A primer set consisting of primers fD3 and T50 (Table 2) was used to specifically amplify the $r s$ gene from spirochetes (18). The PCR was performed as described above, except that the two primers were used at the same concentration $(5 \mu \mathrm{M})$. The amplification reaction was carried out for 30 cycles with an annealing temperature of $54^{\circ} \mathrm{C}$.

The PCR products $(10 \mu \mathrm{l})$ were digested by restriction enzyme $B f a \mathrm{I}$ (New England Biolabs). The restriction products were separated by electrophoresis on a $1.8 \%$ agarose gel in TBE buffer for $2 \mathrm{~h}$ at $120 \mathrm{~V}$. pBR322 digested by HinfI was used as a molecular weight marker.

Protein analysis. Sodium dodecyl sulfate-polyacrylamide gel electrophoresis and immunoblotting were performed as described previously (20). Reactivity with monoclonal antibodies H3TS, D6, and I 17.3, which are specific for $B$. burgdorferi sensu stricto, $B$. garinii, and $B$. afzelii, respectively, was studied as described previously $(1,4,20)$.

Nucleotide sequence accession numbers. The $16 \mathrm{~S}$ ribosomal DNA sequences determined have been deposited in the GenBank database. Their accession numbers are reported in Table 1.

\section{RESULTS AND DISCUSSION}

Sequence comparisons and phylogenetic analysis. $B$. lusitaniae sp. nov. (formerly genomic species PotiB2) has been identified previously on the basis of its DNA relatedness in DNA-DNA hybridization experiments. This genomic species was easily identified by analyzing the restriction pattern of the $r f-r r l$ ribosomal spacer after amplification by PCR (21). In this study, nearly complete $r$ s sequences $(1,509$ to 1,526 nucleotides) were determined for five $B$. lusitaniae sp. nov. strains, accounting for about $96 \%$ of the rrs gene. In order to evaluate the phylogenetic position of $B$. lusitaniae sp. nov., we compared

TABLE 2. Primers used for amplification and sequencing of the $r s$ gene of B. lusitaniae and B. valaisiana

\begin{tabular}{lll}
\hline \multicolumn{1}{c}{ Primer } & \multicolumn{1}{c}{ Sequence $\left(5^{\prime}\right.$ to $\left.3^{\prime}\right)$} & $\begin{array}{c}\text { Position in } \\
\text { B. burgdorferi } \\
\text { sensu stricto }\end{array}$ \\
\hline $\begin{array}{l}\text { PCR primers } \\
\text { fD3 }\end{array}$ & AGAGTTTGATCCTGGCTTAG & $8-27$ \\
T50 & GTTACGACTTCACCCTCCT & $1497-1479$ \\
UniB & T(AC)AAGGAGGTGATCCAGC & $1539-1522$ \\
Sequencing primers & & \\
fD3 & AGAGTTTGATCCTGGCTTAG & $8-27$ \\
S1 & AACGCGTGGATGATCTACCT & $105-124$ \\
RS3 & TTACCCTACCAACTAGCTAAT & $259-239$ \\
S5 & GAGGAATAAGCTTTGTAGGA & $442-462$ \\
RS6 & CTTTACGCCCAATAATCCCGA & $571-551$ \\
S9 & ATTAGATACCCTGGTAGTCT & $784-803$ \\
RS9 & TAACACCAAGTGTGCATCGT & $832-813$ \\
RS11 & CTTAACCCAACACCTCACAGC & $1086-1066$ \\
S13 & AGGAAGGTGAGGATGACGTC & $1169-1188$ \\
RS15 & TAATAGCTTCGGGTATCCTC & $1435-1416$ \\
RS16 & TGATCCAGCCGCACTTTCC & $1531-1512$ \\
\hline
\end{tabular}


TABLE 3. Sequence similarity values

\begin{tabular}{|c|c|c|c|c|c|c|c|c|c|c|c|c|c|c|c|c|c|}
\hline \multirow{2}{*}{ Strain } & \multicolumn{17}{|c|}{$\%$ Sequence similarity to: } \\
\hline & DK7 & Lipitz & $\mathrm{PBi}$ & DK27 & DK1 & DK21 & $\mathrm{HO}^{\mathrm{T}}{ }^{\mathrm{T}}$ & DN127 & $21038^{\mathrm{T}}$ & PotiB1 & PotiB2 ${ }^{\mathrm{T}}$ & PotiB3 & Ir 345 & BR41 & VS116 & UK & Am501 \\
\hline B. burgdorferi DK7 & 100 & 99.8 & 99 & 99.2 & 98.6 & 98.7 & 95.8 & 96.8 & 97.7 & 99 & 99.1 & 99 & 99.2 & 99.2 & 98.8 & 98.7 & 98.9 \\
\hline B. burgdorferi Lipitz & & 100 & 99.2 & 99.4 & 98.8 & 98.9 & 96 & 97 & 98 & 99.2 & 99.3 & 99.2 & 99.4 & 99.4 & 99 & 98.9 & 99 \\
\hline B. garinii $\mathrm{PBi}$ & & & 100 & 99.6 & 98.7 & 98.8 & 95.7 & 96.6 & 97.4 & 99.2 & 99.3 & 99.2 & 99.4 & 99.4 & 99 & 98.9 & 99.1 \\
\hline B. garinii DK27 & & & & 100 & 98.8 & 98.9 & 95.9 & 96.9 & 97.7 & 99.5 & 99.6 & 99.5 & 99.7 & 99.7 & 99.1 & 99 & 99.2 \\
\hline B. afzelii DK1 & & & & & 100 & 99.8 & 95.7 & 96.1 & 97.8 & 98.9 & 98.8 & 98.9 & 98.9 & 98.9 & 99.2 & 99.1 & 99.3 \\
\hline B. afzelii DK21 & & & & & & 100 & 95.7 & 96.2 & 97.8 & 99 & 98.9 & 99 & 99 & 99 & 99.2 & 99.2 & 99.4 \\
\hline B. japonica $\mathrm{HO}^{\mathrm{T}}$ & & & & & & & 100 & 97.6 & 95.3 & 95.8 & 95.9 & 95.8 & 96 & 96 & 95.5 & 95.4 & 95.7 \\
\hline $\begin{array}{l}\text { Genomic species DN127 } \\
\text { strain DN127 }\end{array}$ & & & & & & & & 100 & 95.4 & 96.6 & 96.7 & 96.6 & 96.8 & 96.8 & 96.2 & 96.1 & 96.4 \\
\hline B. andersonii $21308^{\mathrm{T}}$ & & & & & & & & & 100 & 97.8 & 97.7 & 97.8 & 97.8 & 97.8 & 97.6 & 97.5 & 97.8 \\
\hline B. lusitaniae PotiB1 & & & & & & & & & & 100 & 99.9 & 100 & 99.9 & 99.9 & 99.1 & 99 & 99.3 \\
\hline B. lusitaniae PotiB2 ${ }^{\mathrm{T}}$ & & & & & & & & & & & 100 & 99.9 & 99.9 & 99.9 & 99 & 99 & 99.2 \\
\hline B. lusitaniae PotiB3 & & & & & & & & & & & & 100 & 99.9 & 99.9 & 99.1 & 99 & 99.3 \\
\hline B. lusitaniae Ir345 & & & & & & & & & & & & & 100 & 100 & 99.1 & 99 & 99.3 \\
\hline B. lusitaniae BR41 & & & & & & & & & & & & & & 100 & 99.1 & 99 & 99.3 \\
\hline B. valaisiana VS116 & & & & & & & & & & & & & & & 100 & 99.7 & 99.8 \\
\hline B. valaisiana UK & & & & & & & & & & & & & & & & 100 & 99.7 \\
\hline B. valaisiana Am501 & & & & & & & & & & & & & & & & & 100 \\
\hline
\end{tabular}

its $r r s$ sequences with those of $B$. valaisiana (29) and those of other species constituting the $B$. burgdorferi sensu lato complex available in data banks (Table 1). The numbers of mutations in the $16 \mathrm{~S}$ ribosomal DNA sequences of $B$. burgdorferi sensu lato strains were very low, and the levels of similarity between $r r s$ sequences are shown in Table 3 . These results confirm that the divergence of $B$. burgdorferi sensu lato leading to speciation is a recent event. As previously shown for $B$. burgdorferi sensu stricto and $B$. garinii (16), the five $B$. lusitaniae sp. nov. strains exhibit a very high level of relatedness (99.9\%) (Table 3) and differ by only two nucleotides. The rrs sequence similarity between B. valaisiana and B. lusitaniae was 99.0 to $99.3 \%$.

Despite the fact that the level of interspecific sequence variability approaches the level of intraspecific variability within each species, the results of the analysis of the phylogenetic relationships among these closely related species are consistent with the taxonomic position inferred from DNA-DNA hybridization studies. $B$. lusitaniae sp. nov. is clearly a member of a separate cluster (Fig. 1). Phylogenetically, the B. lusitaniae sp. nov. branch is close to $B$. garinii. In contrast, $B$. valaisiana branches closer to $B$. afzelii. This topology is strongly supported by parsimony analysis results (data not shown).

Determination of signature nucleotides. Due to the high level of rrs sequence conservation, the mismatches in nucleotidic sequences between Borrelia strains might be of interest for identification at the species level or at the epidemiological level. Recognition of signature positions in each of the three main species has already been utilized to design primers and probes for identification of $B$. burgdorferi sensu stricto, $B$. garinii, and $B$. afzelii $(15,16)$. Some variable and signature positions could be used to differentiate $B$. lusitaniae sp. nov. from other B. burgdorferi sensu lato strains (Table 4). However, we have to keep in mind that due to intraspecific variability, these signatures must be evaluated with a very large number of strains and must be reevaluated when a new species is described. For example, the signature positions which were chosen to design primers specific for $B$. garinii (15) are also available for $B$. valaisiana and $B$. lusitaniae. We failed to design primers strictly specific for $B$. lusitaniae.

Restriction fragment length polymorphism analysis. To overcome the problem described above, we investigated the restriction site polymorphism of PCR products from the $r$ rs gene. We have previously shown that $B f a \mathrm{I}$ polymorphism provided a simple means for identifying Borrelia species $(18,24)$. PCR primers fD3 and T50 generated 1,488-bp DNA fragments, and their restriction by $B f a$ I allowed us to identify six patterns (Table 1). All but two species can be identified by this means. As we emphasized previously (24), the strains belonging to genomic species DN127 exhibit the same pattern as $B$. burgdorferi sensu stricto, and $B$. japonica strains exhibit the same pattern as $B$. afzelii. However, $B$. lusitaniae sp. nov. and $B$. valaisiana were easily identified by specific patterns (Fig. 2).

Protein analysis. The analysis of protein profiles revealed different patterns for the various Borrelia species (Fig. 3). Although very close to the position of B. valaisiana OspA, OspA from $B$. lusitaniae sp. nov. appeared to be slightly higher (34 $\mathrm{kDa}$. B. lusitaniae Ir345 produced a variant OspA band around $32.5 \mathrm{kDa}$. The size of the OspB protein ranged from 34

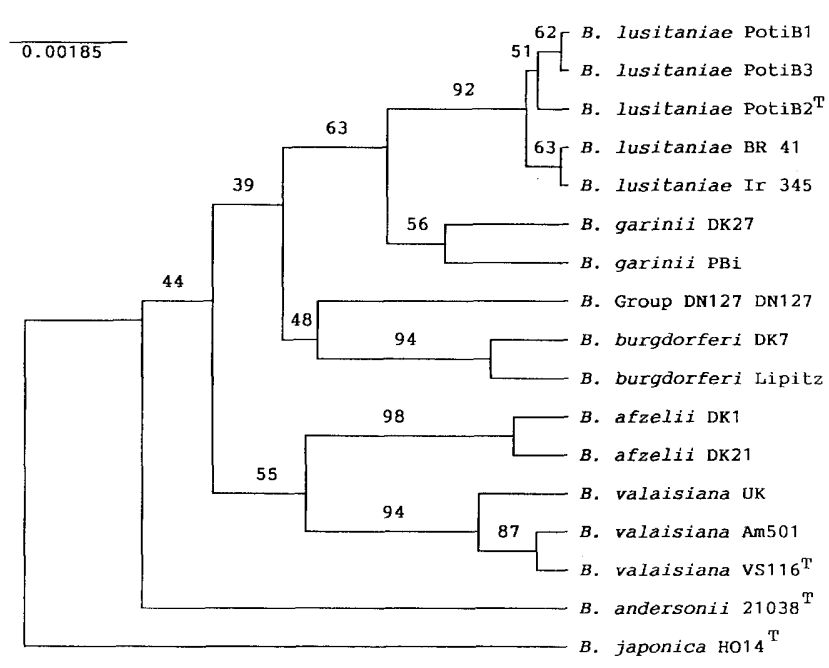

FIG. 1. Phylogenetic tree based on a comparison of the $16 \mathrm{~S}$ rDNA sequences of $B$. burgdorferi sensu lato. The branching pattern was generated by the unweighted pair group with mathematical average method. The values above the lines indicate the percentages of bootstrap replications. The bar represents $0.185 \%$ divergence. 
TABLE 4. B. burgdorferi sensu lato signature and variable nucleotide positions of $16 \mathrm{~S}$ ribosomal DNA

\begin{tabular}{|c|c|c|c|c|c|c|c|c|}
\hline \multirow[b]{2}{*}{ Position ${ }^{\prime \prime}$} & \multicolumn{8}{|c|}{ Nucleotide in ${ }^{b}$ : } \\
\hline & $\begin{array}{c}\stackrel{\Xi}{\Xi} \\
\stackrel{\Xi}{\Xi} \\
\stackrel{\Xi}{\Xi}\end{array}$ & 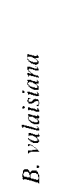 & 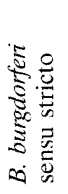 & 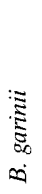 & 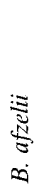 & 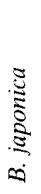 & 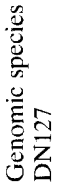 & 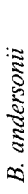 \\
\hline 77 & $\mathrm{C}$ & $\mathrm{T} / \mathrm{C}$ & $\mathrm{C}$ & $\mathrm{C}$ & $\mathrm{C}$ & $\mathrm{C}$ & $\mathrm{C}$ & $\mathrm{C}$ \\
\hline 143 & $\mathrm{C}$ & $\mathrm{C}$ & $\mathrm{T}$ & $\mathrm{T}$ & $\mathrm{C}$ & $\mathrm{C}$ & $\mathrm{T}$ & $\mathrm{T}$ \\
\hline 170 & $\mathrm{~A}$ & $\mathrm{G}$ & $\mathrm{G}$ & A & $\mathrm{G}$ & $\mathrm{G}$ & A & G \\
\hline 253 & $\mathrm{~A}$ & $\mathrm{G}$ & A & A & $\mathrm{G}$ & A & A & A \\
\hline 586 & $\mathrm{~T}$ & $\mathrm{C} / \mathrm{T}$ & $\mathrm{T}$ & $\mathrm{T}$ & $\mathrm{T}$ & $\mathrm{T}$ & $\mathrm{T}$ & $\mathrm{T}$ \\
\hline 627 & $\mathrm{~A}$ & A & $\mathrm{C}$ & A & G & G & $\mathrm{C}$ & G \\
\hline 647 & $T$ & $\mathrm{C} / \mathrm{T}$ & $\mathrm{T}$ & $\mathrm{T}$ & $\mathrm{T}$ & $\mathrm{T}$ & $\mathrm{T}$ & $\mathrm{T}$ \\
\hline 676 & $\mathrm{~T}$ & $\mathrm{C}$ & $\mathrm{T}$ & $\mathrm{T}$ & $\mathrm{C}$ & $\mathbf{T}$ & $\mathrm{T}$ & $\mathrm{T}$ \\
\hline 708 & A & $\mathrm{G}$ & A & A & $\mathrm{G}$ & A & A & G \\
\hline 836 & A & $\mathbf{G}$ & A & A & A & A & A & A \\
\hline 838 & C & A & A & A & A & A & A & A \\
\hline 1133 & $\mathrm{~A} / \mathrm{G}$ & A & G & G & A & G & $\mathrm{G}$ & A \\
\hline 1256 & $\mathrm{G}$ & A & A & A & A & $\mathrm{G}$ & A & A \\
\hline
\end{tabular}

${ }^{a} B$. burgdorferi sensu stricto type strain B31 numbering (9).

${ }^{b}$ Nucleotides of different $B$. burgdorferi sensu lato sequences listed in Table 1 are included for comparison.

$\mathrm{kDa}$ for B. burgdorferi sensu stricto to $35 \mathrm{kDa}$ for $B$. afzelii. This protein seems to be absent from $B$. lusitaniae and from $B$. garinii. In conclusion, the analysis of protein patterns did not provide a reliable means for identification of $B$. lusitaniae. No reactivity of $B$. lusitaniae isolates was observed with monoclonal antibodies H3TS, D6, and I 17.3. Specific monoclonal antibodies would be helpful for differentiating this species at a phenotypic level.

\section{$\begin{array}{llllllllllll}1 & 2 & 3 & 4 & 5 & 6 & 7 & 8 & 9 & 10 & 11\end{array}$}

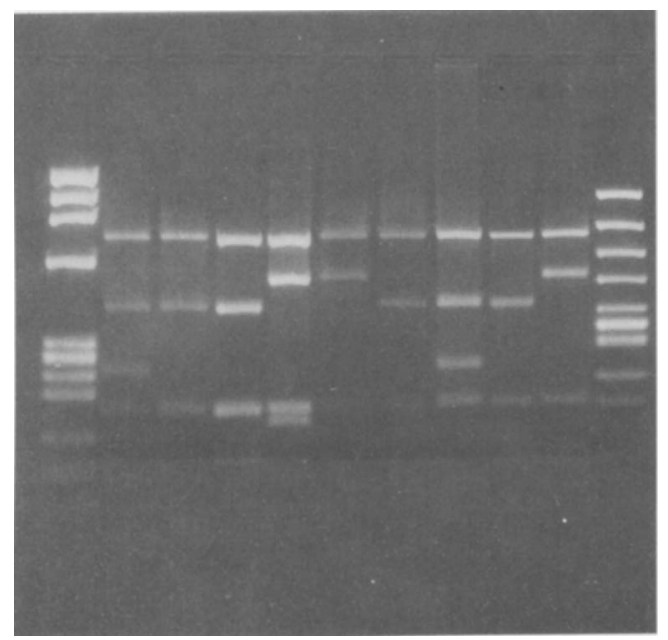

FIG. 2. Restriction patterns of B. burgdorferi sensu lato strains. DNAs from the $r r s$ gene amplified with the primer set consisting of fD3 and T50 were digested by $B f a I$. The DNAs were electrophoresed on a $1.8 \%$ agarose gel, stained with bromide ethidium, and UV illuminated. Lane 1, $\phi$ X-174-RF DNA HincII digest (Pharmacia); lane 2, B. burgdorferi sensu stricto strain $\mathrm{B} 31^{\mathrm{T}}$; lane $3, B$. garinii $20047^{\mathrm{T}}$; lane $4, B$. garinii NT29; lane $5, B$. afzelii VS461 ${ }^{\mathrm{T}}$; lane $6, B$. japonica 0612; lane 7, B. andersonii 21123; lane 8, genomic species DN127 strain DN127; lane 9, B. lusitaniae PotiB2 ${ }^{\mathrm{T}}$; lane 10, B. valaisiana VS116 ${ }^{\mathrm{T}}$; lane 11 , $\phi X-174-R F$ DNA HaelII digest (Pharmacia).

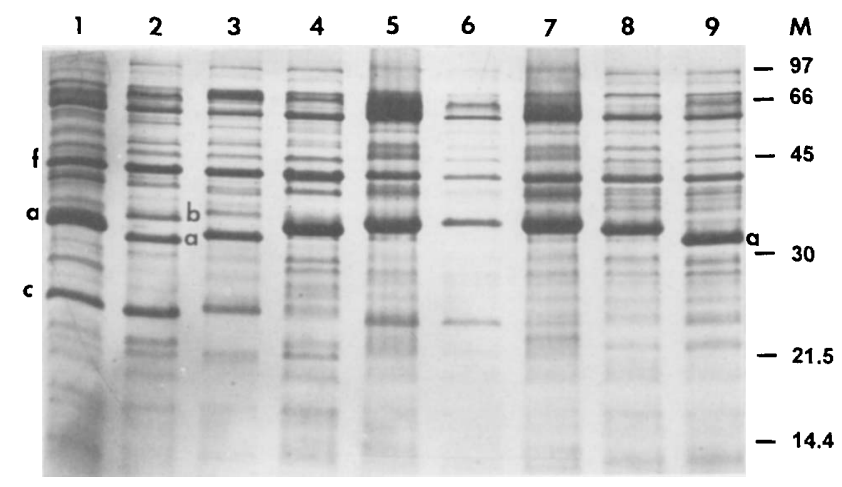

FIG. 3. Coomassie blue-stained sodium dodecyl sulfate-polyacrylamide gel electrophoresis gel of whole cells of $B$. burgdorferi sensu lato isolates. Lane $1, B$. garinii $20047^{\mathrm{T}}$; lane $2, B$. burgdorferi sensu stricto strain $\mathrm{B} 31^{\mathrm{T}}$; lane $3, B$. afzelii VS461 ${ }^{\mathrm{T}}$; lane $4, B$. valaisiana VS116 ${ }^{\mathrm{T}}$; lanes 5 through $9, B$. lusitaniae PotiB1, PotiB2 ${ }^{\mathrm{T}}$, PotiB3, BR41, and Ir345, respectively; lane $M$, low-range protein molecular weight standards (Bio-Rad). f, flagellin; a, OspA; b, OspB; c, OspC.

Habitat. To our knowledge, only seven strains of B. lusitaniae sp. nov. have been isolated. They were all isolated from Ixodes ricinus ticks in Portugal (19), the Czech Republic, Moldavia, Ukraine, and Belorussia (23). However, DNA from $B$. lusitaniae sp. nov. was detected by $\mathrm{PCR}$ in $I$. ricinus ticks from Tunisia (3). The pathogenic potential of this species is unknown.

Description of Borrelia lusitaniae sp. nov. Borrelia lusitaniae (lu.si.tan'i.ae. L. fem. adj. lusitaniae, referring to Lusitania [Portugal], where the organism was first isolated [19]). Morphology as described previously for the genus (13). Cultural properties as described previously for $B$. burgdorferi sensu lato (11). Does not react with monoclonal antibodies H3TS, D6, and I 17.3 specific for B. burgdorferi sensu stricto, B. garinii, and $B$. afzelii, respectively (unpublished data). Can be easily differentiated from other B. burgdorferi sensu lato species by analysis of the MseI restriction polymorphism of the $r r f-r r l$ spacer (21). Patterns after restriction of the $r r s$ gene by $B f a I$ contain six fragments $(689,404,159,100,78$, and $58 \mathrm{bp})$.

The type strain, PotiB2, was isolated from I. ricinus in Portugal.

\section{ACKNOWLEDGMENTS}

We thank E. Korenberg, Z. Hubalek, L. Gern, and M. S. Nuncio for supplying strains and Iain Old for critically reading the manuscript.

We thank the Pasteur Institute for supporting this work. Part of this study was supported by grant 32-40605.94 from the Fonds National Suisse de la Recherche Scientifique.

\section{REFERENCES}

1. Baranton, G., D. Postic, I. Saint Girons, P. Boerlin, J. C. Piffaretti, M. Assous, and P. A. D. Grimont. 1992. Delineation of Borrelia burgdorferi sensu stricto, Borrelia garinii sp. nov., and group VS461 associated with Lyme borreliosis. Int. J. Syst. Bacteriol. 42:378-383.

2. Barbour, A. G. 1984. Isolation and cultivation of Lyme disease spirochetes. Yale J. Biol. Med. 57:521-525.

3. Bouattour, A. 1997. Personal communication.

4. Canica, M. M., F. Nato, L. du Merle, J. C. Mazie, G. Baranton, and D. Postic. 1993. Monoclonal antibodies for identification of Borrelia afzelii sp. nov. associated with late cutaneous manifestations of Lyme borreliosis. Scand. J. Infect. Dis. 25:441-448.

5. Felsenstein, J. 1989. PHYLIP—phylogeny inference package (version 3.2). Cladistics 5:164-166.

6. Fukunaga, M., A. Hamase, K. Okada, H. Inoue, Y. Tsuruta, K. Miyamoto, and M. Nakao. 1996. Characterization of spirochetes isolated from ticks (Ixodes tanuki, Ixodes turdus, and Ixodes columnae) and comparison of the sequences with those of Borrelia burgdorferi sensu lato strains. Appl. Environ. Microbiol. 62:2338-2344.

7. Fukunaga, M., A. Hamase, K. Okada, and M. Nakao. 1996. Borrelia tanukii 
sp. nov. and Borrelia turdae sp. nov. found from ixodid ticks in Japan: rapid species identification by $16 \mathrm{~S}$ rRNA gene-targeted PCR analysis. Microbiol. Immunol. 40:877-881.

8. Fukunaga, M., Y. Takahashi, Y. Tsuruta, O. Matsushita, D. Ralph, M. McClelland, and M. Nakao. 1995. Genetic and phenotypic analysis of Borrelia mivamotoi $\mathrm{sp}$. nov., isolated from the ixodid tick Lxodes persulcatus, the vector for Lyme disease in Japan. Int. J. Syst. Bacteriol. 45:804-810.

9. Gazumyan, A., J. J. Schwartz, D. Liveris, and I. Schwartz. 1994. Sequence analysis of the ribosomal RNA operon of the Lyme disease spirochete, Borrelia burgdorferi. Gene 146:57-65.

10. Higgins, D. G., and R. Sharp. 1989. Fast and sensitive multiple sequence alignments on a microcomputer. CABIOS 5:151-153.

11. Johnson, R. C., G. P. Schmid, F. W. Hyde, A. G. Steigerwalt, and D. J. Brenner. 1984. Borrelia burgdorferi sp. nov.: etiological agent of Lyme disease. Int. J. Syst. Bacteriol. 34:496-497.

12. Kawabata, H., T. Masuzawa, and Y. Yanagihara. 1993. Genomic analysis of Borrelia japonica sp. nov. isolated from Lxodes ovatus in Japan. Microbiol. Immunol. 37:843-848.

13. Kelly, R. T. 1984. Borrelia, p. 57-62. In N. R. Krieg and J. G. Holt (ed.), Bergey's manual of systematic bacteriology, vol. 1. The Williams \& Wilkins Co., Baltimore, Md.

14. Kumar, S., K. Tamura, and N. Masatoshi. 1993. MEGA: molecular evolutionary genetics analysis, version 1.01. The Pennsylvania State University, University Park.

15. Marconi, R. T., and C. F. Garon. 1992. Development of polymerase chain reaction primer sets for diagnosis of Lyme disease and for species-specific identification of Lyme disease isolates by 16S rRNA signature nucleotide analysis. J. Clin. Microbiol. 30:2830-2834.

16. Marconi, R. T., and C. F. Garon. 1992. Phylogenetic analysis of the genus Borrelia: a comparison of North American and European isolates of Borrelia burgdorferi. J. Bacteriol. 174:241-244.

17. Marconi, R. T., D. Liveris, and I. Schwartz. 1995. Identification of novel insertion elements, restriction fragment length polymorphism patterns, and discontinuous 23S rRNA in Lyme disease spirochetes: phylogenetic analyses of rRNA genes and their intergenic spacers in Borrelia japonica sp. nov. and genomic group 21038 (Borrelia andersonii sp. nov.) isolates. J. Clin. Microbiol. 33:2427-2434.
18. Marti Ras, N., B. Lascola, D. Postic, S. J. Cutler, F. Rodhain, G. Baranton, and D. Raoult. 1996. Phylogenesis of relapsing fever Borrelia spp. Int. J. Syst. Bacteriol. 46:859-865.

19. Nuncio, M. S., O. Péter, M. J. Alves, F. Bacellar, and A. R. Filipe. 1993. Isolamento e caracterizaçao de Borrélias de Ixodes ricinus L. em Portugal. Rev. Port. Doenças Infec. 16:175-179.

20. Péter, O., and A. G. Bretz. 1992. Polymorphism of outer surface proteins of Borrelia burgdorferi as a tool for classification. Zentralbl. Bakteriol. Parasitenkd. Infektionskr. Hyg. Abt. 1 Orig. 277:28-33.

21. Postic, D., M. V. Assous, P. A. D. Grimont, and G. Baranton. 1994. Diversity of Borrelia burgdorferi sensu lato evidenced by restriction fragment length polymorphism of $r f(5 \mathrm{~S})-r l$ (23S) intergenic spacer amplicons. Int. J. Syst. Bacteriol, 44:743-752.

22. Postic, D., J. Belfaiza, E. Isogai, I. Saint Girons, P. A. D. Grimont, and G. Baranton. 1993. A new genomic species in Borrelia burgdorferi sensu lato isolated from Japanese ticks. Res. Microbiol. 144:467-473.

23. Postic, D., E. Korenberg, N. Gorelova, Y. V. Kovalevski, E. Bellenger, and G. Baranton. Borrelia burgdorferi sensu lato in Russia and neighboring countries: high incidence of mixed isolates. Res. Microbiol, in press.

24. Ralph, D., D. Postic, G. Baranton, C. Pretzman, and M. McClelland. 1993 Species of Borrelia distinguished by restriction site polymorphisms in $16 \mathrm{~S}$ rRNA genes. FEMS Microbiol. Lett. 111:239-243.

25. Ruimy, R., V. Breittmayer, P. Elbaze, B. Lafay, O. Boussemart, M. Gauthier, and R. Christen. 1994. Phylogenetic analysis and assessment of the genera Vibrio, Photobacterium, Aeromonas, and Plesiomonas deduced from smallsubunit rRNA sequences. Int. J. Syst. Bacteriol. 44:416-426.

26. Saitou, N., and M. Nei. 1987 . The neighbor-joining method: a new method for reconstructing phylogenetic trees. Mol. Biol. Evol. 4:406-425.

27. Swofford, D. L. 1992. PAUP: phylogenic analysis using parsimony, version 3.0. Illinois Natural History Survey, Champaign.

28. Theisen, M., M. Borre, M. J. Mathiesen, B. Mikkelsen, A. M. Lebech, and K. Hansen. 1995. Evolution of the Borrelia burgdorferi outer surface protein OspC. J. Bacteriol. 177:3036-3044.

29. Wang, G., A. P. van Dam, A. Le Fleche, D. Postic, O. Peter, G. Baranton, R. de Boer, L. Spanjaard, and J. Dankert. 1997. Genetic and phenotypic analysis of Borrelia valaisiana sp. nov. (Borrelia genomic groups VS116 and M19). Int. J. Syst. Bacteriol. 47:926-932. 